\title{
Initial Crown Diameter Influences on the Fruit Yield and Quality of Strawberry Pircinque
}

\author{
Antonio Felippe Fagherazzi ${ }^{1, *}$, Daniel Suek Zanin ${ }^{1}$, Marllon Fernando Soares dos Santos ${ }^{1}(\mathbb{D}$, \\ Juliana Martins de Lima ${ }^{1}$, Paola Daiane Welter ${ }^{1}{ }^{1}$, Adrik Francis Richter ${ }^{1}$, Francine Regianini Nerbass ${ }^{1}$, \\ Aike Anneliese Kretzschmar ${ }^{1}$, Leo Rufato ${ }^{1}$ and Gianluca Baruzzi ${ }^{2}$ (D) \\ 1 Centro de Ciências Agroveterinárias da Universidade do Estado de Santa Catarina (CAV-UDESC), \\ Av. Luiz de Camões, 2090, Bairro Conta Dinheiro, Lages 88520-000, Brazil; dsuekzanin@gmail.com (D.S.Z.); \\ marllon.soares@outlook.com (M.F.S.d.S.); juumartinsslima@gmail.com (J.M.d.L.); \\ pdaianew@hotmail.com (P.D.W.); adrikrichter@yahoo.com.br (A.F.R.); fr.nerbass@udesc.br (F.R.N.); \\ aike.kretzschmar@udesc.br (A.A.K.); leo.rufato@udesc.br (L.R.) \\ 2 Council for Agricultural Research and Economics-Centre for Olive, Fruit and Citrus Crops (CREA-OFA), \\ Via La Canapona 1 bis, 47121 Forlì, Italy; gianluca.baruzzi@crea.gov.it \\ * Correspondence: antonio.fagherazzi@udesc.br; Tel.: +55-(49)-9-9947-5051
}

Citation: Fagherazzi, A.F.; Suek Zanin, D.; Soares dos Santos, M.F.; Martins de Lima, J.; Welter, P.D.; Francis Richter, A.; Regianini Nerbass, F.; Anneliese Kretzschmar, A.; Rufato, L.; Baruzzi, G. Initial Crown Diameter Influences on the Fruit Yield and Quality of Strawberry Pircinque. Agronomy 2021, 11, 184. https:// doi.org/10.3390/agronomy11010184

Received: 19 December 2020

Accepted: 14 January 2021

Published: 19 January 2021

Publisher's Note: MDPI stays neutral with regard to jurisdictional claims in published maps and institutional affiliations.

Copyright: (c) 2021 by the authors. Licensee MDPI, Basel, Switzerland. This article is an open access article distributed under the terms and conditions of the Creative Commons Attribution (CC BY) license (https:// creativecommons.org/licenses/by/ $4.0 /)$.

\begin{abstract}
In strawberry production, the combination of a high productive performance and fruits with desirable physicochemical characteristics requires the use of plants with a good quality and high initial vigor. This study aimed to evaluate the effect of plants with different crown diameters on the productive performance and fruit quality of strawberry plants of the cultivar 'Pircinque' (Short Day). The study was conducted in two evaluation cycles (2016/2017 and 2017/2018). The experimental design was divided into randomized blocks, with four repetitions, and plots consisting of 20 plants. This study evaluated the crown diameters of plants of 5, 7, 9, 11, 13, 15, 17, and $19 \mathrm{~mm}$. The productivity and number of fruit values increased significantly by $57 \%$ with larger caliber plants, which also provided precocity of productivity. The use of more vigorous plants also favored the production of fruits with higher soluble solids/titratable acidity ratios $(+28 \%)$ and with epidermis coloration closer to intense red $(-4.3 \%)$. For the cultivar 'Pircinque', plant crown diameters between 15 and $17 \mathrm{~mm}$ are the most favorable because they condition the best productive performances in combination with precocity and a good fruit quality.
\end{abstract}

Keywords: Fragaria $\times$ ananassa; bare-root fresh plants; productive influence; precocity of production

\section{Introduction}

Due to its fruit's qualitative and attractive characteristics, mainly the aroma, flavor, coloration, and firmness, and also due to the high presence of functional compounds, especially polyphenols, anthocyanins, vitamin $C$, and ellagic acid, strawberry (Fragaria $\times$ ananassa Duchesne) is a fruit highly appreciated by consumers [1,2]. In this context, within small fruits, the strawberry plant is the main species cultivated worldwide. In 2018, approximately 8.3 million tons were produced in a cultivated area of 372.3 thousand hectares. China, Poland, Russia, the United States, Turkey, Mexico, and Germany are the leading producers in the world [3]. Despite not being considered an important strawberry producer, Brazil is the leading producer of this fruit in South America [4]. In 2019, approximately 4500 hectares of strawberries were cultivated in Brazil, generating 165 thousand tons and an average productivity of 36.6 tons per hectare [5].

Strawberry production in Brazil has great importance both socially and economically. In the last few years, technologies that promote fruits with a better quality and export potential for foreign markets have been incorporated. In addition to the high economic return and the various ways in which the transformation is permitted regarding the fruit, the strawberry can be found growing across almost all of the Brazilian territory, mainly in 
the states of Minas Gerais, Paraná, the Rio Grande do Sul, São Paulo, Brasília, Espírito Santo, Bahia, and Santa Catarina [5-8].

More than 300 million strawberry plants are needed annually to meet producers' demand. Of this demand, approximately $70 \%$ of the plants are produced in Brazil (bareroot fresh plants), and approximately 30\% are imported (frigo plants) from Argentina, Chile, and Spain [5,7]. However, most of the strawberry plants produced in Brazil lack sanitary and physiological quality, and the nurseries in this sector require more significant technological innovation and a more professional approach. In this sense, the supply of different plants, especially plants with a high vigor and physiological and sanitary quality, is an improvement required to meet strawberry producers' demand.

In Brazil, the plant is perceived as one of the principal investments in implementing a strawberry crop. However, it is a critical factor for the success of cultivation since it is directly related to the fruits' qualitative characteristics. Above all, it is related to the agronomic aspects, especially the size and quantity of fruits harvested. Therefore, plants are considered the starting point for both crop and producer success $[9,10]$. The prerequisites are high indices of vigor and physiological and phytosanitary quality, and the capability to promote a high survival rate and vegetative growth after planting [11-13].

The strawberry plants' vigor can be affected by several factors and the initial diameter of the crown is one of the essential variables for the development of the plant, and is directly related to the accumulation and levels of carbohydrates. They alter the productive characteristics, precocity, and seasonality of production [11,13]. Several studies indicate that crown diameters above $5.1 \mathrm{~mm}$ are not able to increase the successful healing rate of plants after planting [11], and crown diameters above $8.8 \mathrm{~mm}$ allow positive effects for initial and total fruit production [14]. Other studies also indicate positive correlations between the plant crown diameter and total fruit production [15-17] and suggest that vigorous plants are associated with early production $[18,19]$. It is also emphasized that strawberry cultivars can behave differently in adverse conditions. It is essential to determine a minimum and maximum crown diameter standard for different cultivars, with the aim of directing producers and nurseries towards success in their activities.

Given the above, for the development and growth of the strawberry production chain in Brazil, it is essential that studies remedy deficiencies concerning quality standards of bare-root fresh plants produced in the country, as well as determine the crown diameter ranges, so that higher productive and qualitative indices of fruits can be achieved.

Therefore, the purpose of this study was to evaluate the effect of different crown diameters of strawberry plants on the production and quality variables of the fruits of the cultivar Pircinque, cultivated in the mountain region of the state of Santa Catarina, Brazil.

\section{Materials and Methods}

\subsection{Plant Material and Experimental Design}

The experiment was conducted during agricultural harvest periods (April 2016 to January 2017 and April 2017 to January 2018) at the Center of Agroveterinary Sciences of the State University of Santa Catarina (CAV-UDESC), located in the city of Lages, mountain region of the state of Santa Catarina, Brazil. The experimental area is located at the coordinates of $27^{\circ} 47^{\prime}$ south latitude and $50^{\circ} 18^{\prime}$ west longitude, and an altitude of $923 \mathrm{~m}$ above sea level. According to Köppen classification, the city of Lages has a humid subtropical mesothermal climate $(\mathrm{Cfb})$ with moderate summers and winters with a high incidence of frost, having an average annual temperature of $15.6{ }^{\circ} \mathrm{C}$ and an average annual rainfall of $1400 \mathrm{~mm}$, well-distributed throughout the year [20]. The local soil is classified as Haplumbrept [21].

Strawberry plants of the type "bare-root fresh plants" (Figure 1) and the cultivar Pircinque (Short Day) were classified at five months of age, according to the crown diameters $(5,7,9,11,13,15,17$, and $19 \mathrm{~mm})$, and thus constituted the eight treatments evaluated. The plants were produced by a commercial nursery located in the city of São Francisco de Paula $\left(29^{\circ} 06^{\prime}\right.$ S, $50^{\circ} 50^{\prime} \mathrm{W}$, and $900 \mathrm{~m}$ altitude), State of Rio Grande do Sul, 
Brazil. The experimental design involved randomized blocks, with four repetitions, and an experimental unit consisting of 20 useful plants ( 80 plants per treatment). Conventional cultivation was carried out in the soil, in a micro tunnel system. Soil correction and basic fertilization were based on the recommendations for strawberry culture in the Manual of Fertilization and Liming for the state of Santa Catarina [22], and included adjusting the soil $\mathrm{pH}$ to 6.0 , using dolomitic limestone.

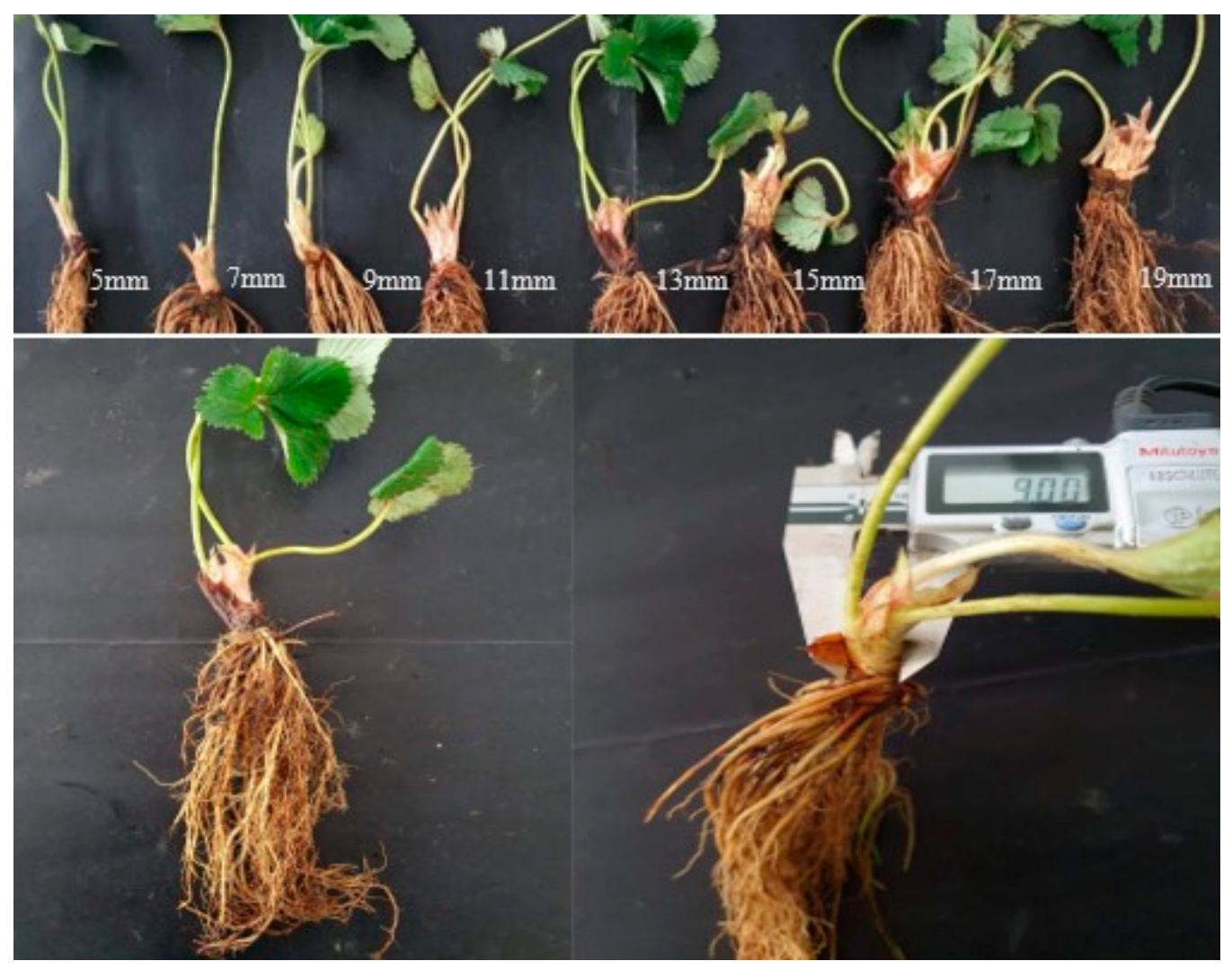

Figure 1. Strawberry plants of the type "bare-root fresh plants" from the cultivar Pircinque, classified according to different crown diameters.

After the stage of fertilizer incorporation into the soil, the beds were prepared with the aid of a rotating Enchantress hoe and building beds that were $0.90 \mathrm{~m}$ wide and $0.25 \mathrm{~m}$ high. Subsequently, three localized irrigation lines with drippers spaced $0.15 \mathrm{~m}$ apart were installed at each plot. The beds were covered with black polyethylene film with a 30 micron thickness and a micro tunnel covering system, using a transparent polyethylene film with a 100 micron thickness [23]. The cultivation technique used in the research is still the most used productive model among Brazilian strawberry producers [7]. The plant spacing was $30 \mathrm{~cm}$ between rows and plants, resulting in a density of 60 thousand plants per hectare.

The planting of plants was conducted in the second half of April of each cycle. Daily activities were carried out to open and close the low tunnels, in order to control the plants' temperature, humidity, and foliar wetting. Fertilization via irrigation (fertigation) was carried out three times a week, providing the following products: Calcium nitrate $\left[\mathrm{Ca}\left(\mathrm{NO}_{3}\right)_{2}\right]$ (9.92 g to 100 plants); magnesium sulfate $\left(\mathrm{MgSO}_{4}\right)$ (4.55 g to 100 plants); potassium sulfate $\left(\mathrm{K}_{2} \mathrm{SO}_{4}\right)$ (31.25 g to 100 plants); monoammonium phosphate (MAP) (38.74 g to 100 plants); and P-51 (fertilizer, a liquid containing approximately $51 \%$ of the soil) (up $7.3 \mathrm{~mL}$ to 100 plants). The harvests were carried out from September to January of each year and carried out every 3 to 5 days. The fruits were harvested during the day's cooler hours, and when $80 \%$ of the fruit epidermis was a uniform red color. Climatic data relating to the temperature $\left({ }^{\circ} \mathrm{C}\right)$, relative humidity $(\%)$, and precipitation $(\mathrm{mm})$ were monitored through the meteorological station of the National Institute of Meteorology (Table 1) [24]. 
Table 1. Mean values of environmental variables measured in the 2016/2017 and 2017/2018 production cycles.

\begin{tabular}{|c|c|c|c|c|c|}
\hline & $\begin{array}{l}\text { Mean Temperature } \\
\left.\text { (Tmed; }{ }^{\circ} \mathrm{C}\right)\end{array}$ & $\begin{array}{l}\text { Maximum Temperature } \\
\left(\text { Tmax; }{ }^{\circ} \mathrm{C}\right)\end{array}$ & $\begin{array}{l}\text { Minimum Temperature } \\
\left.\text { (Tmin; }{ }^{\circ} \mathrm{C}\right)\end{array}$ & $\begin{array}{l}\text { Relative Humidity } \\
\text { (RH; \%) }\end{array}$ & Rainfall (mm) \\
\hline \multicolumn{6}{|c|}{$2016 / 2017$} \\
\hline April & 18.7 & 19.2 & 18.2 & 84.1 & 132.4 \\
\hline May & 12.3 & 12.7 & 11.9 & 86.6 & 123.8 \\
\hline June & 9.0 & 9.5 & 8.4 & 82.1 & 25.0 \\
\hline July & 11.4 & 12.0 & 10.9 & 82.3 & 121.2 \\
\hline August & 12.5 & 13.0 & 11.9 & 82.0 & 136.0 \\
\hline September & 13.3 & 13.8 & 12.7 & 77.5 & 110.4 \\
\hline October & 15.2 & 15.7 & 14.7 & 83.2 & 207.8 \\
\hline November & 17.3 & 17.9 & 16.7 & 77.0 & 70.4 \\
\hline December & 19.2 & 19.8 & 18.6 & 80.6 & 154.8 \\
\hline January & 20.8 & 21.5 & 20.3 & 80.3 & 114.8 \\
\hline Average & 15.0 & 15.5 & 14.4 & 81.6 & 119.7 \\
\hline \multicolumn{6}{|c|}{$2017 / 2018$} \\
\hline April & 15.8 & 16.4 & 15.3 & 83.6 & 86.4 \\
\hline May & 14.5 & 15.0 & 14.2 & 91.0 & 108.2 \\
\hline June & 12.2 & 12.7 & 11.8 & 88.5 & 90.5 \\
\hline July & 11.9 & 12.5 & 11.4 & 81.0 & 83.4 \\
\hline August & 12.7 & 13.3 & 12.3 & 83.9 & 106.2 \\
\hline September & 17.9 & 18.5 & 17.3 & 77.5 & 26.2 \\
\hline October & 16.4 & 17.0 & 15.8 & 78.5 & 78.6 \\
\hline November & 17.1 & 17.7 & 16.5 & 74.2 & 67.4 \\
\hline December & 19.8 & 20.5 & 19.3 & 78.0 & 150.6 \\
\hline January & 19.7 & 20.3 & 19.1 & 82.6 & 187.2 \\
\hline Average & 15.8 & 16.3 & 15.2 & 82.1 & 98.5 \\
\hline
\end{tabular}

\subsection{Analyzed Variables}

\subsubsection{Productive Parameters}

All the fruits of each plot and treatment were harvested. It was possible to estimate the variable number of fruits per plant (unit Plant ${ }^{-1}$ ) by dividing the total number of fruits harvested by the number of plants present in each experimental unit. The total production $\left(\mathrm{g} \mathrm{plant}^{-1}\right.$ ) was obtained by dividing the total weight of the fruits harvested by the number of plants contained in the plot [25]. The fresh mass per fruit ( $\mathrm{g}$ fruit ${ }^{-1}$ ) was obtained by dividing the commercial production, in grams per plant, by the number of commercial fruits in each experimental unit. The percentage of commercial production (\%) was estimated by dividing, in each parcel, commercial production by total production, and then multiplying the results by 100 . For commercial production, they were considered fruits without any anomalies (considered symptoms of rot and deformity) and fruits with a fresh mass equal to or greater than $10 \mathrm{~g}$ [25]. All weighing measurements were carried out with a precision digital scale $(0.01 \mathrm{~g})$, certified by the National Institute of Metrology, Quality, and Technology (INMETRO) [26].

\subsubsection{Qualitative Parameters}

For the variable of fruit quality, we grouped uniform samples of 10 fruits per plot. Fruit quality analyses were performed four times during the production cycles. The coloration parameters of the fruit epidermis were obtained through a digital countertop colorimeter by Konica Minolta CHROMA METER CR-400 (Made in Japan). For each fruit, two readings were performed on opposite sides of the equatorial region: By colorimetric analysis, the variable of lightness (L), which is provided by a scale of 0 to 100 , ranging from low to high of the darker to lighter colors; the chroma (C), which indicates the epidermis purity or saturation of color, which can range from 0 to 60 , ranging in an ascending order of the colors, from less saturated to more saturated; and the hue angle ( ${ }^{\circ}$ hue), which sets the tone of the skin, ranging from 0 to 360, in which the lowest values correspond to tones closest to deep red, and higher values indicate tones closer to red-orange. 
The pulp firmness was obtained with a digital countertop penetrometer (Texture Analyser TA.XT.plusC-made in United States of America), with $6.0 \mathrm{~mm}$ diameter tips. For each fruit, two readings were performed on opposite sides of the equatorial region. The results were expressed as the Newton force needed to break through the fruit epidermis. The titratable acidity was obtained with an automatic titrator (TITRONIC ${ }^{\circledR} 300$-made in Germany). For each experimental unit, a sample of $5 \mathrm{~mL}$ of fruit juice was diluted in $45 \mathrm{~mL}$ of distilled water, followed by titration with $0.1 \mathrm{M} \mathrm{NaOH}$ solution, until $\mathrm{pH} 8.1$ was obtained. The results were expressed as a percentage of citric acid per $100 \mathrm{~g}$ of fresh fruit mass. The soluble solids content was determined using a digital countertop refractometer (Atago PR-101A, with automatic temperature correction-made in Japan). For this purpose, samples of $20 \mathrm{~mL}$ of fruit juice from each plot were used. The results were expressed in degrees Brix ( ${ }^{\circ}$ Brix). The soluble solids/titratable acidity ratio was calculated by dividing the soluble solids content results by the titratable acidity of each plot.

\subsection{Statistical Analysis}

The resulting data were submitted to an analysis of variance (ANOVA) by the F test, and in the cases of significance, quadratic polynomial regression analysis was performed. To better understand the relationship between the variables analyzed concerning the different crown diameters of the evaluated plants, the averages were submitted to the principal component analysis (PCA) multivariate procedure [27]. The study also analyzed the productive seasonality by dividing the total production ( $\mathrm{g} \mathrm{plant}^{-1}$ ) by the harvest months in each treatment. In this procedure, all of the different plant crown diameters and harvest months were compared, in a factorial scheme, using analysis of variance and the Scott-Knott test for grouping means, with a 5\% error probability. All statistical analyses were performed using $\mathrm{R}$ software [28].

\section{Results and Discussion}

For the two years of evaluation (2016/2017 and 2017/2018), significant polynomial regression adjustments were verified for all evaluated variables.

A significant effect was observed for the different plant crown diameters in both harvests regarding the productive yield parameters. In terms of the number of fruits per plant, the plants' increase in the crown diameter resulted in increments for this variable, which were adjusted in quadratic models in both crop cycles (Figure 2A). In the 2016/2017 harvest, the largest number of fruits per plant (more than 40 fruits) was obtained with the largest crown diameter $(19 \mathrm{~mm})$. Therefore, it is impossible to estimate the curve's maximum point. In the $2017 / 2018$ agricultural cycle, a maximum point of approximately 60 plant $^{-1}$ fruits was obtained for the crown diameter of $15.8 \mathrm{~mm}$. In both production cycles, the total production per plant increased quadratically with the plants' crown diameter (Figure 2B). The highest averages for total production were obtained with the largest evaluated crown diameter of $19 \mathrm{~mm}$, being $650 \mathrm{~g} \mathrm{plant}^{-1}$ for the 2016/2017 harvest and 815 g plant $^{-1}$ for the $2017 / 2018$ harvest. It was possible to find a minimum point indicating that significant results require crown diameters greater than 14.0 and $12.2 \mathrm{~mm}$ for the respective harvests.

The increase in the number of fruits and the highest product performance in this study (Figure 2A), with the increase in plant crown diameters, has already been obtained by other authors, who have verified an increase in the number of fruits in strawberry plants using plants with crown diameters between 15 and $17 \mathrm{~mm}$ [29]. One of the principal explanations is that larger diameter plants, besides having a higher energy reserve in the form of starch, have a high number of buds capable of differentiating into flowers and fruits [14], resulting in increases in the number of fruits per plant and total production. These authors also verified higher productive yields in two evaluation cycles for plants with a larger crown diameter $(>10 \mathrm{~mm})$ than plants with a smaller crown diameter, corresponding to an $18 \%$ and $27 \%$ increment, for the first and second harvests, respectively. They also verified a $17 \%$ increase in total production in plants with a diameter between 10 and $17 \mathrm{~mm}$, compared to 
plants with a diameter of less than $10 \mathrm{~mm}$ [12]. With larger plants, there is an increase in the plant's biomass, which favors its photosynthetic machinery [30].
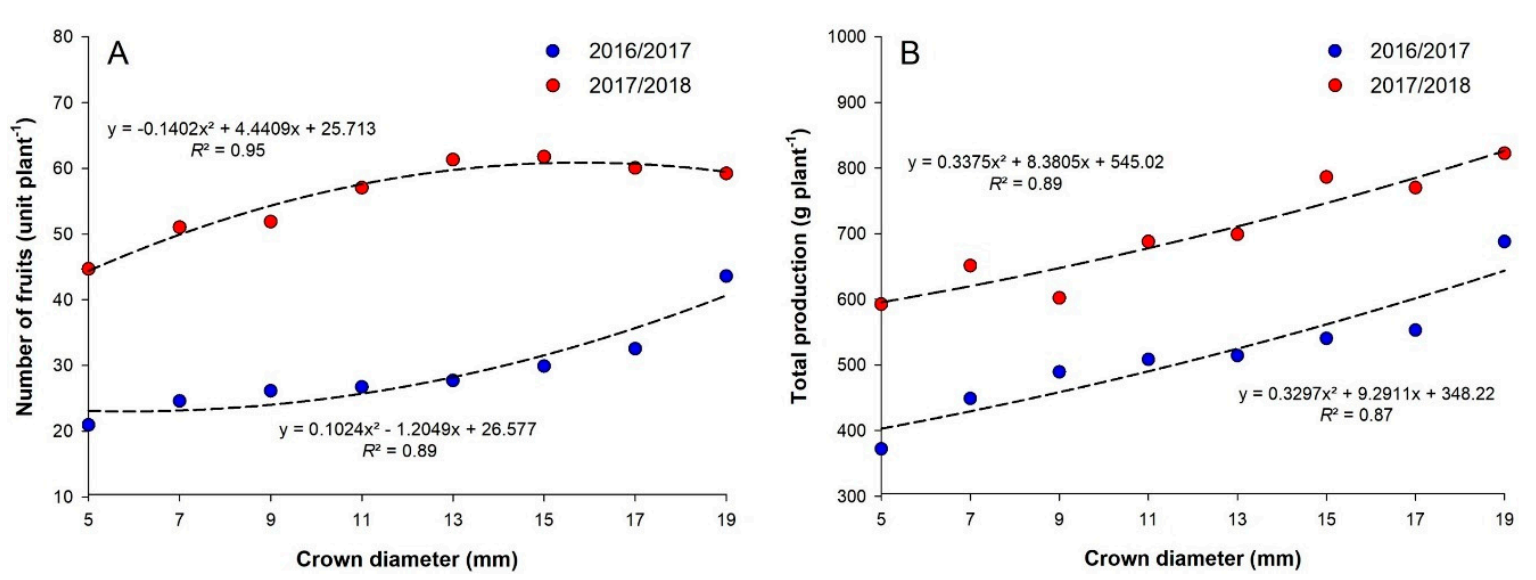

Figure 2. The number of fruits per plant (A) and the total production (B) of strawberry plants cv. 'Pircinque', according to different plant crown diameters $(5,7,9,11,13,15,17$, and $19 \mathrm{~mm})$ in the 2016/2017 and 2017/2018 production cycles.

The higher accumulation of biomass in plants is related to a higher density of foliage, which raises the productive capacity to a limited extent. When the optimal leaf area index is reached, the plant's ability to intercept light energy is favored, thus increasing organic compound production through photosynthesis, resulting in increased production [31]. Moreover, larger strawberry plants also result in plants with a more vigorous root system, allowing a higher absorption of water and nutrients by plants [32], which also benefits their production yield.

The crowns have the function of regulating the metabolic activities of strawberry plants [33]. They are also the plant's main energy storage organ, accumulating reserve substances inside, notably starch [34]. Therefore, the use of vigorous plants is an advantage, mainly during the initial fruiting period, since part of the initial production is dependent on the accumulation of reserves in the crown during plant development $[12,14]$. The crowns' number and diameter also serve as parameters for estimating strawberry plant production [35].

In the 2016/2017 cycle, there was an increase in the average mass of commercial fruits, with positive quadratic behavior and a maximum point of $21.43 \mathrm{~g}_{\text {fruit }}{ }^{-1}$, obtained for the plant crown diameter of $11.8 \mathrm{~mm}$ (Figure 3A). In the 2017/2018 harvest, there was a small decrease in the fresh mass of commercial fruits using more vigorous plants, estimated at a minimum point of $17.75 \mathrm{~g}$ fruit ${ }^{-1}$, for the diameter of $15.9 \mathrm{~mm}$. The sharpest decrease in fresh fruit mass in the 2016/2017 cycle, after the maximum point, may be related to the increase in the number of fruits, leading to an increase in competition among fruits by assimilates, resulting in a reduction in the average mass [36].

The percentage of commercial production exhibited a small amount of variation between the different treatments. However, there was a significant difference between them (Figure 3A). In both harvests, positive quadratic curves were obtained for this variable. However, in the 2016/2017 harvest, the commercial fruit production amount was higher than in the $2017 / 2018$ harvest. This is possibly due to the higher number of fruits per plant obtained in the 2017/2018 cycle, which resulted in a higher production of fruits below the commercial standard of $10 \mathrm{~g}$ per fruit, due to the need to distribute the assimilates to a larger number of fruits. The maximum percentage of commercial production was obtained with the diameters of $12.06 \mathrm{~mm}$ for $2016 / 2017$ and $12.16 \mathrm{~mm}$ for $2017 / 2018$, with values of $91.8 \%$ and $79.7 \%$, respectively. 

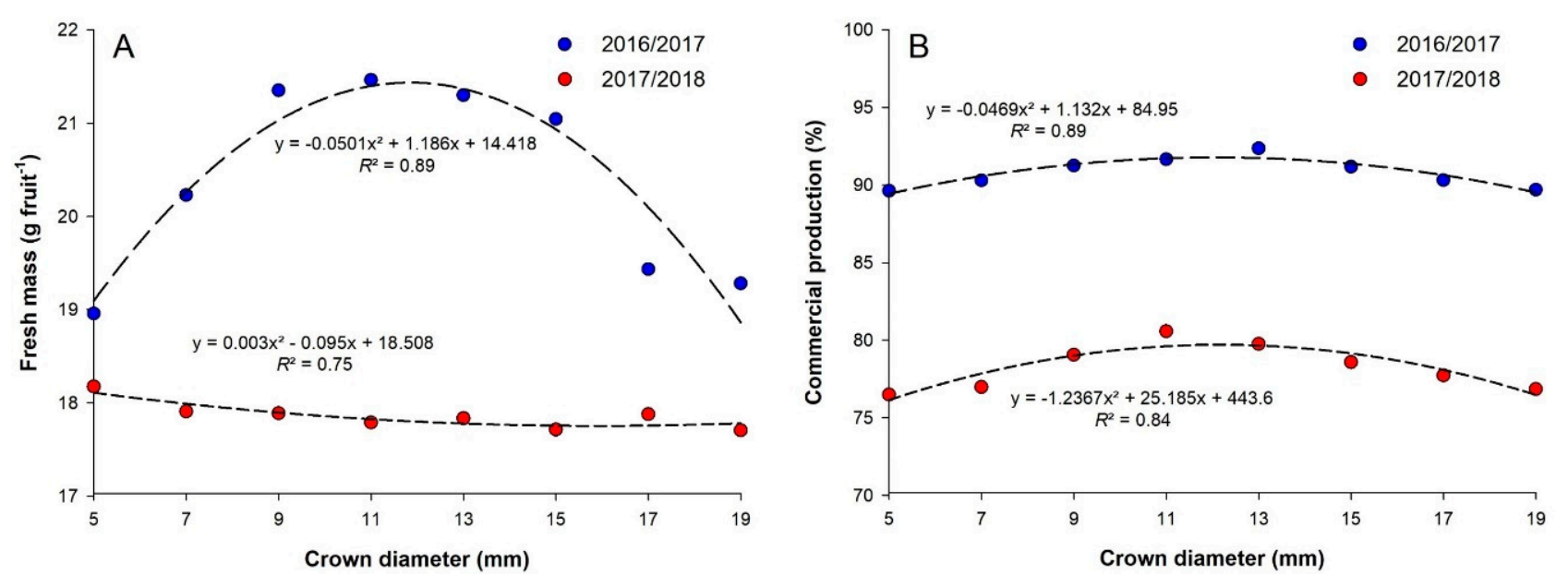

Figure 3. The response of fresh fruit mass (A) and the percentage of production classified as commercial (B) of strawberry plants cv. 'Pircinque', depending on different plant crown diameters $(5,7,9,11,13,15,17$, and 19 mm) in the production cycles 2016/2017 and 2017/2018.

Other studies also reported productivity increases followed by a decrease in the average mass of fruits with the use of more vigorous strawberry plants, with an increase in the number of fruits and yield, but without an increase in the average weight of fruits with the use of bare-root plants with a diameter above $10 \mathrm{~mm}$ [14].

In the 2016/2017 harvest, the percentage of commercial fruits increased with more vigorous plants, up to a crown diameter of $12.5 \mathrm{~mm}$, with an estimated $92 \%$ of commercial production (Figure 3B). In the 2017/2018 cycle, the maximum value for this variable was estimated to be $79 \%$ for the plant diameter of $12 \mathrm{~mm}$. The commercial production percentage suffered small reductions from the crown diameter of $15 \mathrm{~mm}$ and higher due to increased fruit production, with less than $10 \mathrm{~g}$ in both harvests. The use of more vigorous strawberry plants usually results in plants with less stress, making them less susceptible to attacks by pathogens [30]. The crown diameter is one of the main parameters of the plant quality [12], and plants with a high physiological quality lead to high commercial fruit yields [32].

Regarding the fruit quality parameters, decreases in the titratable acidity were observed using plants with a larger crown diameter for the two harvests that were part of this study. The curves were aligned to quadratic models (Figure 4A). In the 2016/2017 harvest, the minimum value was obtained for the diameter of $14 \mathrm{~mm}$, with an estimated value of $0.54 \%$ citric acid. In the $2017 / 2018$ agricultural cycle, the use of more vigorous plants also resulted in a decrease in the titratable acidity, but one that was less pronounced, with a minimum value for the $13.8 \mathrm{~mm}$ diameter $(0.58 \%$ citric acid). The titratable acidity, together with the sugar content, makes up the taste of the fruits. However, when the acidity is high, the sugar content must be as well, so that there is no compromise in consumer fruit taste and acceptance [37]. Therefore, for the market acceptance regarding the taste, a balance in the soluble solids / titratable acidity ratio is necessary. In the 2016/2017 harvest, there was a reduction in acidity values when the crown diameters increased and a simultaneous increase in soluble solids (Figure 4B), increasing the soluble solids/titratable acidity ratio (Figure 5A). Therefore, in this harvest, the fruits were tastier due to increased sugar levels, resulting in sweeter fruits. 

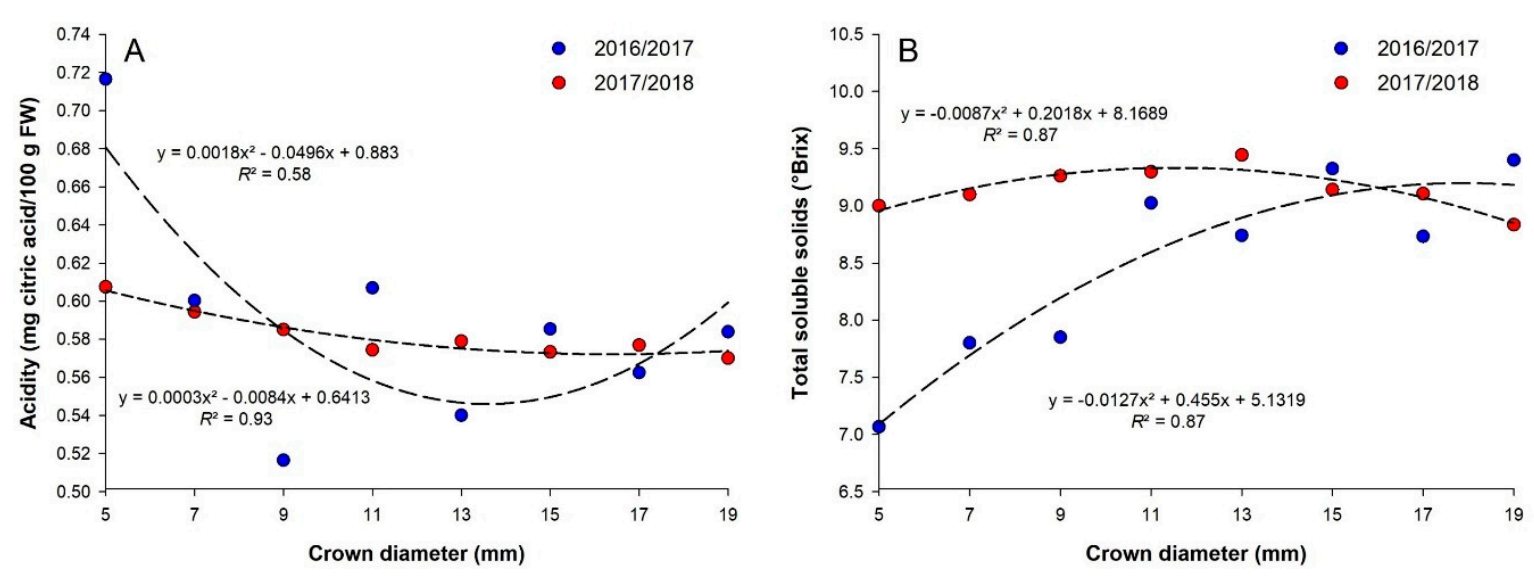

Figure 4. The titratable acidity (A) and total soluble solids content (B) in the fruits of strawberry plants cv. 'Pircinque', depending on different crown diameters of the plants $(5,7,9,11,13,15,17$, and $19 \mathrm{~mm})$ during the 2016/2017 and 2017/2018 production cycles.
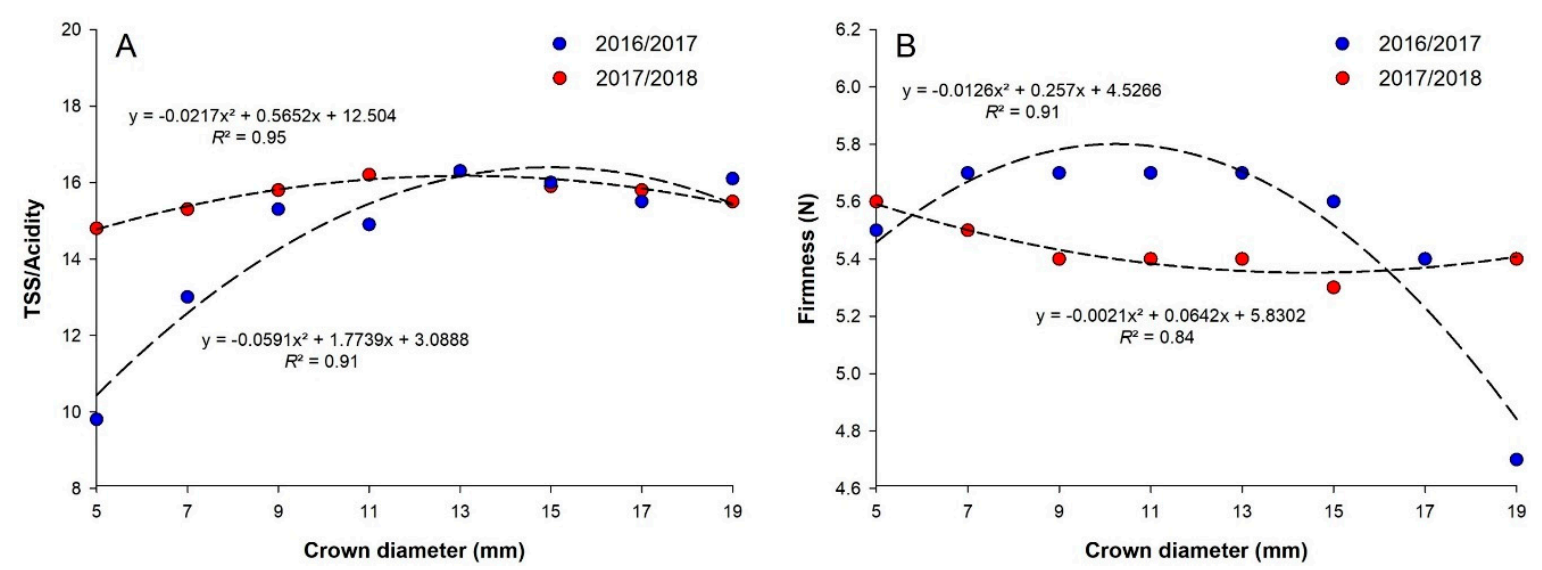

Figure 5. The response of the ratio between the content of soluble solids (TSS) by titratable acidity (A) and pulp firmness (B) of the fruits of strawberry plants cv. 'Pircinque', depending on different crown diameters of the plants $(5,7,9,11,13,15$, 17, and $19 \mathrm{~mm}$ ) during the 2016/2017 and 2017/2018 production cycles.

For the soluble solids content, quadratic increases were observed when using larger plants, but with different intensities, for the two analyzed harvests (Figure 4B). In the 2016/2017 production cycle, the maximum estimate for the sugar concentration $\left(9.2^{\circ}\right.$ Brix) was obtained with the diameter of $17.9 \mathrm{~mm}$. In the $2017 / 2018$ harvest, the maximum content of soluble solids $\left(9.3^{\circ}\right.$ Brix) was obtained with the plant diameter of $11.6 \mathrm{~mm}$. The soluble sugar content in fruits is due to several polysaccharides from the photosynthesis process, mainly glucose, fructose, and sucrose. During fruit ripening, the production and concentrations of these compounds increase, and the reserve starch is converted into simple carbohydrates, which are soluble in water [38]. This is a possible explanation for why more vigorous plants resulted in sweeter fruits in the present study, highlighting the importance of having plants with an excellent physiological quality and high crown caliber, as well as those that are richer in terms of the carbohydrate reserve [13].

As for the soluble solids/titratable acidity ratio, there were also significant effects due to the different plant sizes, with positive quadratic behavior in both crops (Figure 5A). In the 2016/2017 cycle, the maximum value for this variable (16.4) was found for the plant crown diameter of $15 \mathrm{~mm}$ (Figure 5A). In the 2017/2018 harvest, the maximum value (16.5) was obtained for the plant diameter of $11.6 \mathrm{~mm}$. In this cycle, the soluble solids/titratable acidity ratio averages were lower than in the 2016/2017 cycle. This was the case because, 
in the 2017 / 2018 harvest, both the reduction in the titratable acidity and the increase in the sugar content in fruits, resulting from the use of more vigorous plants, occurred at lower intensities when compared to the 2016/2017 cycle (Figure 4A,B). Therefore, there were lower estimates of the soluble solids/titratable acidity ratio (Figure 5A).

The soluble solids/titratable acidity ratio is one of the most important fruit quality parameters. It allows us to verify the existing balance between the concentration of sugars and acidity, making this parameter more representative than isolated estimates of the titratable acidity and soluble solids content [39].

For the fruit pulp's firmness, there was also a significant effect provided by the use of plants with different crown diameters, and quadratic regression curves were obtained for both crop cycles (Figure 5B). In the 2016/2017 harvest, there was an increase in pulp firmness values, up to the estimated average of $5.86 \mathrm{~N}$, corresponding to the crown diameter of $10.5 \mathrm{~mm}$. However, for crown diameters above $13 \mathrm{~mm}$, a sharp decrease in the averages was obtained for this variable, reaching $4.74 \mathrm{~N}$ for the largest crown diameter evaluated (19 $\mathrm{mm}$ ). In the 2017/2018 cycle, the regression curve obtained resulted in a minimum value of $5.35 \mathrm{~N}$ for the plant crown diameter of $15 \mathrm{~mm}$. In this harvest, the oscillation in fruit pulp's firmness averages provided by the different crown diameters of the plants was much lower than in the previous cycle.

In strawberry production, the fruits' pulp firmness is one of the most relevant characteristics to take into account. Fruits with firmer pulp are usually better accepted by consumers, more resistant to transport, have a longer shelf life after harvest [40], and are more resistant to rot caused by pathogens [36]. This requires combining the fruits' taste attributes (balance between sweetness and acidity) with appropriate pulp firmness values to ensure marketing and maintenance of the fruits' quality for the longest possible period post-harvest.

Three variables, considered separately, were employed to evaluate the epidermis coloration. Both production cycles (2016/2017-2017/2018) showed similar behavior. For the variable luminosity of epidermis (Figure 6A), a greater luminosity was observed in the fruit of plants with a crown diameter of 5 and $7 \mathrm{~mm},(>40.0)$. Plants with a crown diameter of $13 \mathrm{~mm}$ generated lower luminosity values, being between 38.6 and 39.2. The luminosity ranges from 0 to 100, from darker colors (smaller values) to lighter colors (larger values).

For the variable chroma or epidermis' color saturation (Figure 6B), higher averages were observed in fruits from plants with a crown diameter between 5 and $9 \mathrm{~mm}$, with averages higher than 49.0; that is, epidermis with a purer or saturated color. Lower chroma averages were found in the fruits from plants with crown diameters between 15 and $19 \mathrm{~mm}$ (averages between 48.0 and 48.5). As for the hue angle (Figure 6C), which determines the epidermis' color tone, the highest values were found in fruits produced from plants with a diameter of $5 \mathrm{~mm}$, with an average of 36.4 in the first production cycle $(2016 / 2017)$, and 36.0 in the second (2017/2018). In fruits from plants with a diameter of $13 \mathrm{~mm}$, the lowest hue angle values were observed (33.8 in the first production cycle and 33.6 in the second cycle).

Considering the three variables of coloration together, it is possible to observe that in the fruits that had the lightest epidermis, with the highest luminosity averages, the saturation was also higher, that is, a more vivid color, and also a shade closer to light red or orange. The external epidermis color of strawberry fruits is one factor that most influences the consumers' purchase intention and fruits with more intense, bright red coloration and free of defects tend to be more desirable in the in natura consumer market [37].

Pigments belonging to the anthocyanin group are responsible for the red color in strawberry fruits [41]. The main anthocyanins in strawberry fruits are pelargonidin 3-glucoside and cyanidin 3-rutinoside, with the former being present at a higher concentration [42]. 

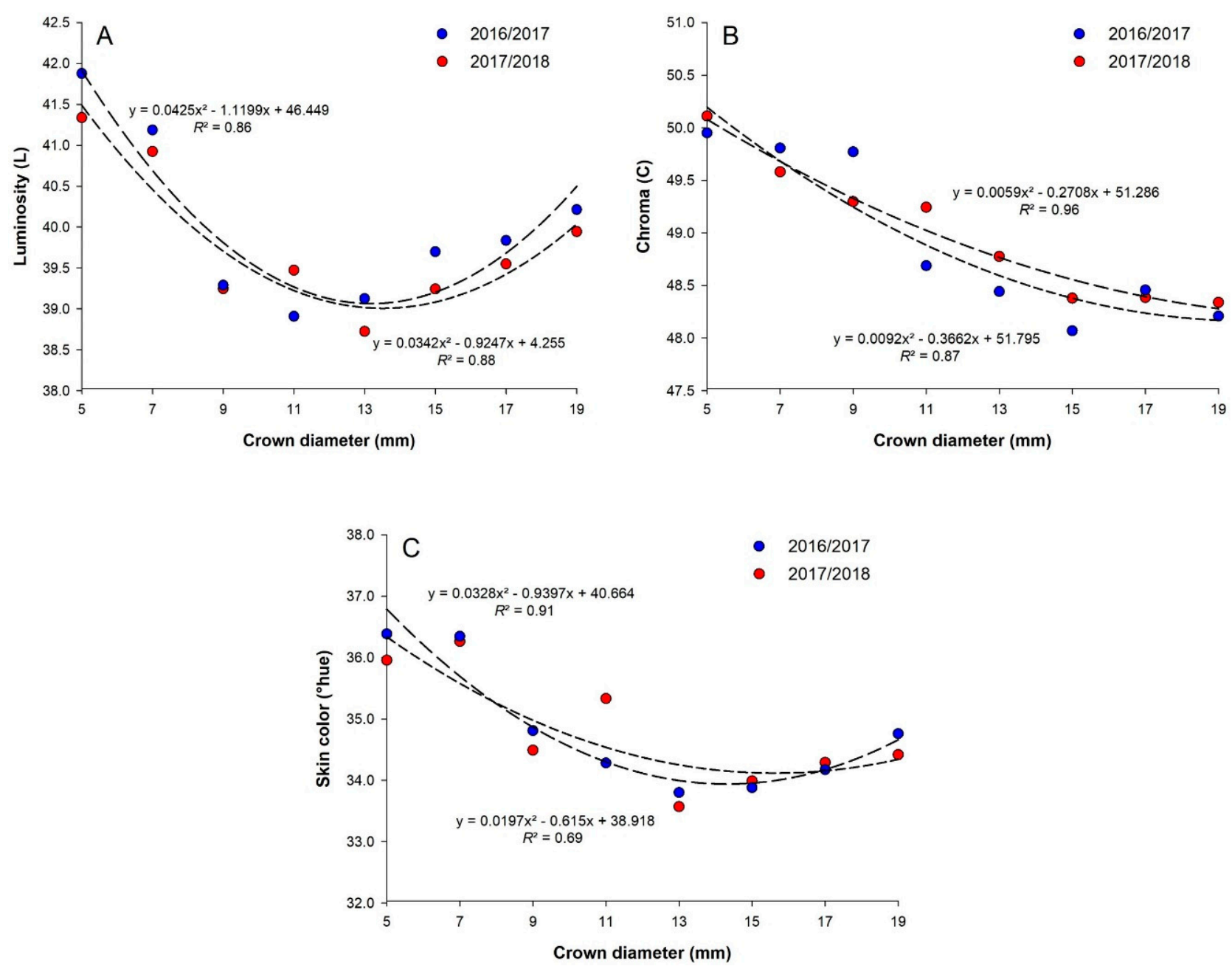

Figure 6. The response of the parameters related to the fruit's epidermis coloration, represented by the values of luminosity (A), chroma (B), and the skin color $\left({ }^{\circ}\right.$ hue) (C) in strawberry plants cv. 'Pircinque', depending on different plant crown diameters $(5,7,9,11,13,15,17$, and $19 \mathrm{~mm})$ in the 2016/2017 and 2017/2018 production cycles.

In the principal component analysis (Figure 7), the first two components represented $92.2 \%$ of the variation obtained (63.8\% for Axis 1 and $28.4 \%$ for Axis 2$)$, allowing the treatments' graphical dispersion and variables to be analyzed in a two-dimensional graph (Figure 7). The main component 1 was related to the variable soluble solids/titratable acidity ratio, soluble solids content, number of fruits per plant, hue angle of the fruit epidermis, chroma, luminosity, total production, and titratable acidity (Figures 7 and 8). Plant crown diameters of 17 and $19 \mathrm{~mm}$ were the most strongly correlated with the total production and number of fruits per plant (Figure 7). The $15 \mathrm{~mm}$ treatment, in turn, was closely related to the soluble solids content and the soluble solids/titratable acidity ratio. On the other hand, the smaller crown diameters evaluated $(5$ and $7 \mathrm{~mm}$ ) were related to higher titratable acidity, luminosity, chroma, and hue angle values.

On the other hand, the variables commercial fruits' average mass, percentage of commercial production, and pulp firmness were responsible for most of the variation present in the main component 2 (Figures 7 and 8). Plant crown diameters of 9, 11, and $13 \mathrm{~mm}$ were the treatments most closely related to these variables (Figure 7). 


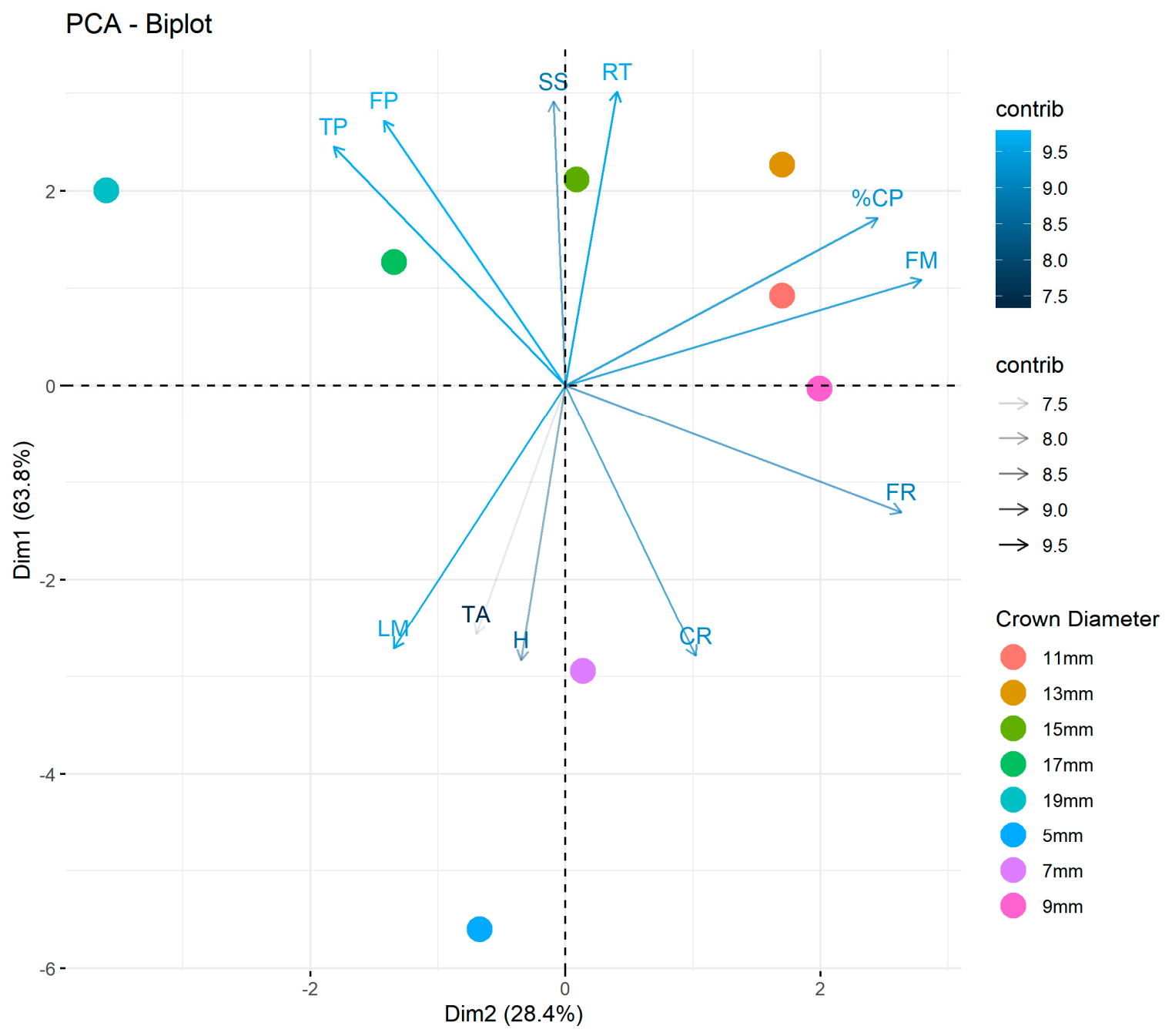

Figure 7. Principal component analysis of the variables in the study concerning the effect of bare-root plants with different crown diameters $(5,7,9,11,13,15,17$, and $19 \mathrm{~mm})$ on the production and fruit quality parameters of strawberry plants cv. Pircinque. Caption: $\mathrm{FP}=$ fruits per plant; $\mathrm{TP}=$ total production; $\mathrm{FM}=$ fresh mass; $\% \mathrm{CP}=\mathrm{commercial}$ percentage; $\mathrm{SS}=$ content of soluble solids; $\mathrm{FR}$ = firmness; $\mathrm{TA}$ = titratable acidity; $\mathrm{RT}$ = soluble solids/titratable acidity ratio; $\mathrm{LM}=$ epidermis luminosity; $\mathrm{CR}=$ epidermis chroma; and $\mathrm{H}=$ epidermis hue angle.

In a general approach to the analysis of the main components, it is possible to affirm that the plant crown diameters from 15 to $17 \mathrm{~mm}$ were closely related to the most important agronomic characteristics for the strawberry crop (productivity, soluble solids/acidity ratio, and pulp firmness). The plants with the largest evaluated crown diameter $(19 \mathrm{~mm})$ were related to the highest yields in the two evaluation cycles and high ratios between the soluble solids content and titratable acidity. However, a sharp drop in the pulp firmness values occurred in the 2016/2017 harvest, when plants with a $19 \mathrm{~mm}$ crown diameter were used (Figure 5B), which suggests that new studies need to be carried out to investigate the feasibility of using plants with this caliber, for the cultivar 'Pircinque'.

As a multivariate analysis modality, the analysis of main components is a handy tool in agricultural research in terms of identifying the most recommended treatments, taking into account the largest number of possible variables [43]. Therefore, this type of analysis often supports more precise conclusions being drawn from a research project's result than the exclusive use of univariate analyzes, which often leave doubts in terms of the most effective treatments measurement [44]. This can be especially important in the case of a crop such as strawberry, in which the yield and fruit quality parameters are equally relevant $[36,40]$. 

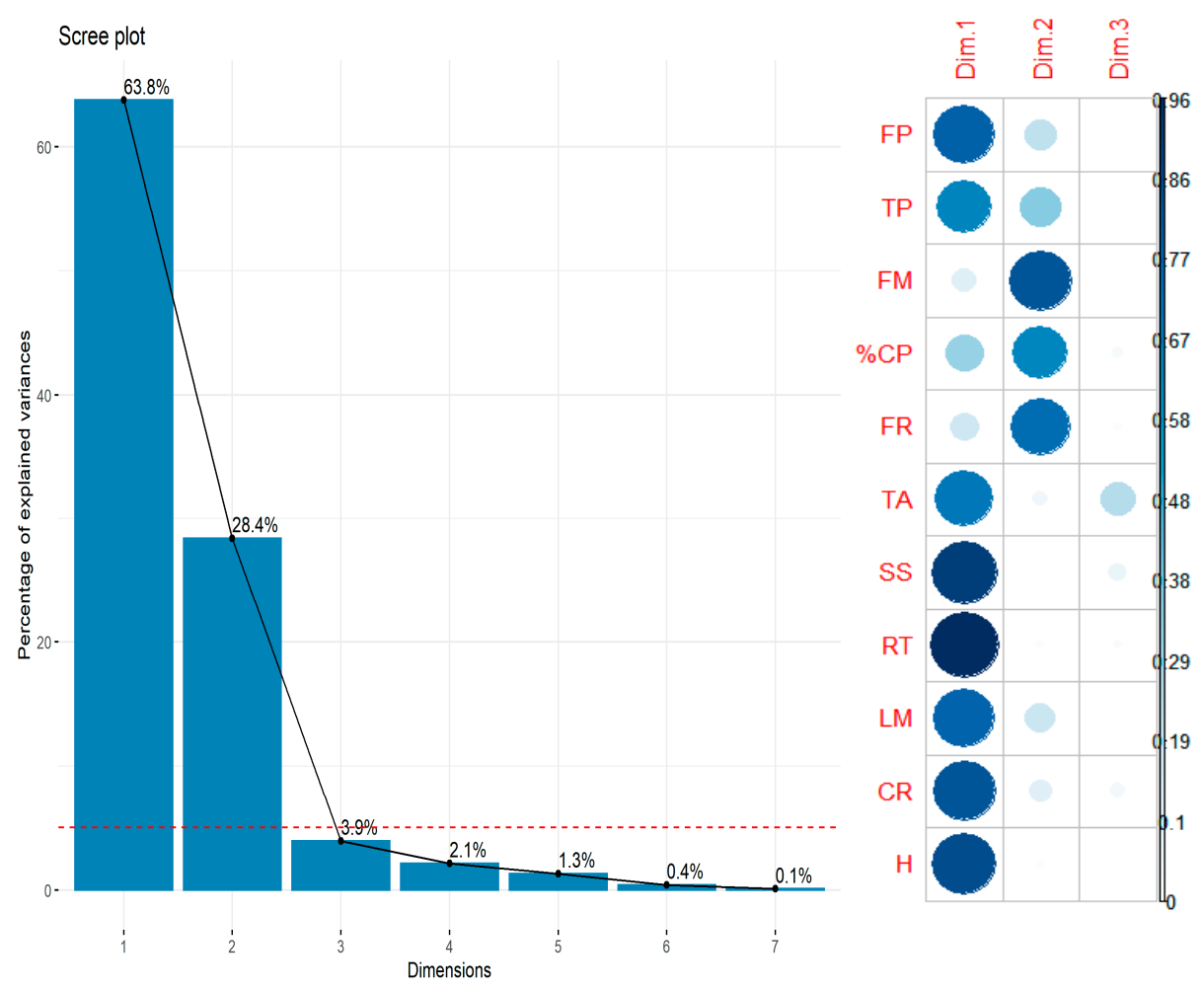

Figure 8. Decomposed principal component analysis for the variables in the study concerning the effect of bare-root plants with different crown diameters $(5,7,9,11,13,15,17$, and $19 \mathrm{~mm})$ on the production and fruit quality parameters of strawberry plants cv. Pircinque. Caption: FP = fruits per plant; $\mathrm{TP}=$ total production; $\mathrm{FM}=$ fresh mass; $\% \mathrm{CP}=$ commercial percentage; $\mathrm{SS}=$ content of soluble solids; FR = firmness; TA = titratable acidity; RT = soluble solids/titratable acidity ratio; $\mathrm{LM}$ = epidermis luminosity; $\mathrm{CR}=$ epidermis chroma; and $\mathrm{H}=$ epidermis hue angle.

The use of plants of different calibers provided different results for the seasonality of the strawberry plants cv. 'Pircinque' total production, for both harvests studied. There was an interaction between plant crown diameters and harvest months (Tables 1 and 2). In the 2016/2017 cycle, the largest productions occurred in November for most of the treatments evaluated (Table 2). Exceptions were the plant crown diameter of $7 \mathrm{~mm}$, with the largest yields in November and December, with no significant difference between these months, and the diameter of $19 \mathrm{~mm}$, with the highest averages in October, November, and December. In the 2017/2018 cycle, the highest total productions were obtained in October for most of the treatments evaluated (Table 3). The exception was the crown diameter of $5 \mathrm{~mm}$, with the highest production in November.

Taking into account the influence of plant crown diameters within each harvest month, it was found that, in the two harvests studied, the use of more vigorous plants resulted in a higher precocity in the productive phase; that is, significantly higher yields compared to smaller diameter plants at the beginning of each harvest (Tables 2 and 3). In the 2016/2017 cycle, for example, for the first month of harvest (September), the yields with crown diameters of 17 and $19 \mathrm{~mm}$ were significantly higher than those of the other plant sizes. In October 2016, the largest diameter plants $(19 \mathrm{~mm})$ provided the most significant results, differing from other treatments. On the other hand, in November of that year, there was no significant influence of the plant sizes on the production averages, while in December, the crown diameter of $19 \mathrm{~mm}$ resulted in the largest productions. In January, corresponding to the final phase of the productive period, the different plant sizes provided similar productivity results. 
Table 2. Productive seasonality of strawberry plants cv. 'Pircinque', from plants with different crown diameters, in the agricultural cycle of 2016/2017.

\begin{tabular}{|c|c|c|c|c|c|c|}
\hline Treatment & SET & OCT & NOV & DEC & JAN & Average \\
\hline $5 \mathrm{~mm}$ & $7.0 \mathrm{dD} *$ & $53.8^{\mathrm{cD}}$ & $132.7^{\mathrm{aB}}$ & $92.6^{b C}$ & $85.9^{\mathrm{bA}}$ & 74.4 \\
\hline $7 \mathrm{~mm}$ & $6.8^{\mathrm{cD}}$ & $87.8^{\mathrm{bC}}$ & $158.6^{a B}$ & $129.1^{a B}$ & $66.3^{\mathrm{bA}}$ & 89.7 \\
\hline $9 \mathrm{~mm}$ & $16.6^{\mathrm{eC}}$ & $93.4^{\mathrm{cC}}$ & $178.0^{\mathrm{aA}}$ & $135.0^{\mathrm{bB}}$ & $66.3^{\mathrm{dA}}$ & 97.9 \\
\hline $11 \mathrm{~mm}$ & $24.7^{\mathrm{dC}}$ & $105.3^{\mathrm{bC}}$ & $195.8^{\mathrm{aA}}$ & $111.9^{b C}$ & $70.2^{\mathrm{cA}}$ & 101.6 \\
\hline $13 \mathrm{~mm}$ & $32.0^{\mathrm{cB}}$ & $139.6^{\mathrm{bB}}$ & $184.1^{\mathrm{aA}}$ & $109.2 \mathrm{bC}$ & $49.3^{\mathrm{cA}}$ & 102.8 \\
\hline $15 \mathrm{~mm}$ & 41.9 cB & $128.9 \mathrm{bB}$ & $182.9^{\mathrm{aA}}$ & $133.0 \mathrm{bB}$ & $53.5^{\mathrm{cA}}$ & 108.0 \\
\hline $17 \mathrm{~mm}$ & $49.3^{\mathrm{cA}}$ & $136.0^{\mathrm{bB}}$ & $185.2^{\mathrm{aA}}$ & $125.9^{b B}$ & $56.4^{\mathrm{cA}}$ & 110.6 \\
\hline $19 \mathrm{~mm}$ & $62.5^{\mathrm{bA}}$ & $203.5^{\mathrm{aA}}$ & $187.6^{\mathrm{aA}}$ & $171.5^{\mathrm{aA}}$ & $62.7^{\mathrm{bA}}$ & 137.6 \\
\hline Average & 30.1 & 118.5 & 175.6 & 126.0 & 63.8 & \\
\hline
\end{tabular}

CV 11.21

* Averages followed by the same lowercase letters in the rows, and uppercase letters in the columns, belong to the same group, as determined by the Scott-Knott test, with a 5\% error probability.

Table 3. Productive seasonality of strawberry plants cv. 'Pircinque', from plants with different crown diameters, in the agricultural cycle of 2016/2017.

\begin{tabular}{ccccccc}
\hline Treatment & SET & OCT & NOV & DEC & JAN & Average \\
\hline $5 \mathrm{~mm}$ & $23.7^{\mathrm{dB} *}$ & $144.6^{\mathrm{bC}}$ & $199.2^{\mathrm{aA}}$ & $145.5^{\mathrm{bA}}$ & $79.3^{\mathrm{cA}}$ & 118.5 \\
$7 \mathrm{~mm}$ & $36.9^{\mathrm{dB}}$ & $222.1^{\mathrm{aA}}$ & $175.5^{\mathrm{bA}}$ & $148.6^{\mathrm{bA}}$ & $68.1^{\mathrm{cA}}$ & 130.2 \\
$9 \mathrm{~mm}$ & $58.6^{\mathrm{cA}}$ & $202.1^{\mathrm{aB}}$ & $125.0^{\mathrm{bA}}$ & $152.3^{\mathrm{bA}}$ & $63.8^{\mathrm{cA}}$ & 120.3 \\
$11 \mathrm{~mm}$ & $59.1^{\mathrm{cA}}$ & $242.7^{\mathrm{aA}}$ & $172.4^{\mathrm{bA}}$ & $156.9^{\mathrm{bA}}$ & $56.6^{\mathrm{cA}}$ & 137.5 \\
$13 \mathrm{~mm}$ & $65.4^{\mathrm{cA}}$ & $241.8^{\mathrm{aA}}$ & $172.6^{\mathrm{bA}}$ & $152.9^{\mathrm{bA}}$ & $66.3^{\mathrm{cA}}$ & 139.8 \\
$15 \mathrm{~mm}$ & $78.0^{\mathrm{cA}}$ & $271.0^{\mathrm{aA}}$ & $187.4^{\mathrm{bA}}$ & $182.6^{\mathrm{bA}}$ & $67.1^{\mathrm{cA}}$ & 157.2 \\
$17 \mathrm{~mm}$ & $64.0^{\mathrm{cA}}$ & $288.0^{\mathrm{aA}}$ & $163.5^{\mathrm{bA}}$ & $183.9^{\mathrm{bA}}$ & $70.4^{\mathrm{cA}}$ & 154.0 \\
$19 \mathrm{~mm}$ & $86.4^{\mathrm{cA}}$ & $298.0^{\mathrm{aA}}$ & $177.7^{\mathrm{bA}}$ & $188.4^{\mathrm{bA}}$ & $71.9^{\mathrm{cA}}$ & 164.5 \\
Average & 59.0 & 238.8 & 171.7 & 163.9 & 67.9 & \\
\hline CV & & & 12.06 & & &
\end{tabular}

* Averages followed by the same lowercase letters in the rows, and uppercase letters in the columns, belong to the same group, as determined by the Scott-Knott test, with a $\%$ error probability.

In the 2017/2018 harvest, for the first month of the harvest (September), the use of plants with a crown diameter of $9 \mathrm{~mm}$ or higher provided higher production averages than smaller plants ( 5 and $7 \mathrm{~mm}$ ). In the second month of that harvest (October), plants with any crown diameter from $7 \mathrm{~mm}$ resulted in higher yields than plants with a crown diameter of $5 \mathrm{~mm}$. On the other hand, in November, December, and January, the caliber had no significant influence on the total production.

When analyzing both harvests together regarding the productive seasonality, one of the most important results was that larger caliber plants favored higher yields in the first two months of each harvest, namely, a higher productive precocity. The early production of fruits in the strawberry plants is directly correlated with the plant quality at planting [32]. Among the factors related to the quality of the plants that most influence the strawberry plant production and precocity, the crown diameter, the mass of the aerial part, and the quality and volume of the root system stand out [45]. In plants with a smaller crown diameter, the peak production is observed later when compared with plants with a larger diameter.

\section{Conclusions}

Plants with large crown diameters provide superior results regarding the productive performance of strawberry plants cv. 'Pircinque', and improve the quality of the harvested fruits, compared with less vigorous plants.

The use of plants with crown diameters of 15 and $17 \mathrm{~mm}$ leads to higher yields and precocity values, and a high physical-chemical quality of the fruits. 
The use of strawberry plants with a diameter of less than $9 \mathrm{~mm}$ promotes a decrease in the production capacity and a delay in the start of production.

For strawberry plants of the type "bare-root fresh plants" of cultivar 'Pircinque', it is recommended that plants with a crown diameter greater than $9 \mathrm{~mm}$ are used.

Author Contributions: Conceptualization, A.F.F.; methodology, A.F.F., D.S.Z., M.F.S.d.S., and L.R.; validation and formal analysis A.F.F., D.S.Z., and M.F.S.d.S.; investigation and data curation, A.F.F., D.S.Z., P.D.W., M.F.S.d.S., J.M.d.L., and A.F.R.; writing-original draft preparation, M.F.S.d.S., J.M.d.L., and P.D.W.; writing-review and editing, visualization, A.F.F., D.S.Z., F.R.N., A.A.K., and L.R.; supervision, project administration, and funding acquisition, A.A.K., L.R., and G.B. All authors have read and agreed to the published version of the manuscript.

Funding: This research was funded by Universidade do Estado de Santa Catarina (UDESC).

Data Availability Statement: Data sharing not applicable. No new data were created or analyzed in this study. Data sharing is not applicable to this article.

Acknowledgments: The authors are grateful for the infrastructure and logistical support provided by the Center for Agroveterinary Sciences of the University of the State of Santa Catarina (CAV-UDESC); by the research development agencies, especially FAPESC and CNPq; for the grant of scholarships; and for the assistance with research activities. They also thank the Fruit Crop research team of CAV-UDESC and the Council for Agricultural Research and Economics-Centre for Olive, Fruit and Citrus Crops (CREA-OFA) for supporting scientific cooperation with UDESC. Finally, they thank the Pasa nursery for providing the plants used in this research.

Conflicts of Interest: The authors declare no conflict of interest.

\section{References}

1. Cervantes, L.; Ariza, M.T.; Miranda, L.; Lozano, D.; Medina, J.J.; Soria, C.; Martínez-Ferri, E. Estabilidade dos traços de qualidade das frutas de diferentes variedades de morango em condições ambientais variáveis. Agronomy 2020, 10, 1242. [CrossRef]

2. Chaves, V.C.; Boff, L.; Vizzotto, M.; Calvete, E.; Reginatto, F.H.; Simões, C.M. Berries grown in Brazil: Anthocyanin profiles and biological properties. J. Sci. Food Agric. 2018, 11, 4331-4338. [CrossRef]

3. FAO-Food and Agriculture Organization of the United Nations. Countries by Commodity. Available online: http://www.fao. org/faostat/en/\#data/QC (accessed on 14 November 2020).

4. Fagherazzi, A.F.; Kretzschmar, A.; Macedo, T.A.; Vignolo, G.K.; Antunes, L.E.C.; Kirschbaum, D.; Franquez, G.G.; Zoppolo, R.; Jofrè, F.; Rufato, L. La coltivazione dei piccoli frutti in Sud America: Non solo mirtilli. Frutticoltura 2017, 7, 44-47.

5. Antunes, L.E.C.; Bonow, S.; Reisser Júnior, C. Morango: Crescimento constante em área e produção. Campo E Neg. 2020, 1, 88-92.

6. Gonçalves, M.A.; Cocco, C.; Picoloto, L.; Vignolo, G.K.; Antunes, L.E.C. Diâmetro de coroa e presença de folhas na produção de mudas de morangueiro. In Embrapa Clima Temperado-Artigo em Anais de Congresso, Congresso Brasileiro de Fruticultura, Bento Gonçalves, Brasil, 2012; Anais; SBF: Bento Gonçalves, Brazil, 2012.

7. Fagherazzi, A.F.; Grimaldi, F.; Kretzschmar, A.A.; Molina, A.R.; Gonçalves, M.A.; Antunes, L.E.C.; Baruzzi, G.; Rufato, L. Strawberry production progress in Brazil. Acta Hortic. 2016, 1156, 937-940. [CrossRef]

8. Rigon, L. Anuário Brasileiro da Fruticultura; Editora Gazeta: Santa Cruz do Sul, Brazil, 2015; p. 104.

9. Oliveira, R.P.; Scivittaro, W.B. Desempenho produtivo de mudas nacionais e importadas de morangueiro. Rev. Bras. Frutic. 2006, 28, 520-522. [CrossRef]

10. Oliveira, R.P.; Nino, A.F.P.; Scivittaro, W.B. Mudas certificadas de morangueiro: Maior produção e melhor qualidade da fruta. A Lavoura 2005, 108, 35-38.

11. Cocco, C.; Andriolo, J.L.; Cardoso, F.L.; Erpen, L.; Schmitt, O.J. Crown size and transplant type on the strawberry yield. Sci. Agric. 2011, 68, 489-493. [CrossRef]

12. Menzel, C.M.; Smith, L. Relationship between the levels of non-structural carbohydrates, digging date, nursery-growing environment, and chilling in strawberry transplants in a subtropical environment. HortScience 2012, 47, 459-464. [CrossRef]

13. Cocco, C.; Gonçalves, M.A.; Reisser Júnior, C.; Marafon, A.C.; Antunes, L.E.C. Carbohydrate content and development of strawberry transplants from Rio Grande do Sul and imported. Rev. Bras. Frutic. 2016, 38, e581. [CrossRef]

14. Torres-Quezada, E.A.; Zotarelli, L.; Whitaker, V.M.; Santos, B.M.; Hernandez-Ochoa, I. Initial crown diameter of strawberry bare-root transplants affects early and total fruit yield. HortTechnology 2015, 25, 203-208. [CrossRef]

15. Johnson, C.; Raiford, T.; Whitley, K. Initial crown diameter of transplants influences marketable yield components of two strawberry cultivars in annual hill production system. Int. J. Fruit Sci. 2005, 5, 23-29. [CrossRef]

16. Bartczak, M.; Lisiecka, J.; Knaflewski, M. Correlation between selected parameters of planting material and strawberry yield. Folia Hortic. 2010, 22, 9-12. [CrossRef] 
17. Peper, P.J.; McPherson, E.G.; Mori, S.M. Equations for predicting diameter, height, crown width, and leaf area of San Joaquin Valley street trees. J. Arboric. 2001, 27, 306-317.

18. Bish, E.B.; Cantliffe, D.J.; Chandler, C.K. Temperature conditioning and container size affect early season fruit yield of strawberry plug plants in a winter, annual hill production system. HortScience 2002, 37, 762-764. [CrossRef]

19. Giménez, G.; Andriolo, J.L.; Janish, D.J.; Cocco, C.; Dal Picio, M. Tamanho da célula em bandejas para a produção de transplantes de morango. Pesqui. Agropecu. Bras. 2009, 44, 726-729. [CrossRef]

20. Embrapa-Empresa Brasileira de Pesquisa Agropecuária. Solos do Estado de Santa Catarina. In Centro Nacional de Pesquisa de Solos; EMBRAPA: Brasilia, Brazil, 2004; p. 726.

21. Embrapa-Empresa Brasileira de Pesquisa Agropecuária. Sistema Brasileiro de Classificação de Solos. In Centro Nacional de Pesquisa de Solos, 3rd ed.; EMBRAPA: Rio de Janeiro, Brazil, 2013; p. 306.

22. CQFS. Comissão de Química e Fertilidade do Solo-RS/SC. In Manual de Calagem e Adubação Para os Estados do Rio Grande do Sul e de Santa Catarina; Evangraf: Porto Alegre, Brazil, 2016; p. 376.

23. Oliveira, R.P.; Scivittaro, W.B. Desempenho produtivo de cultivares de morangueiro. Sci. Agrar. 2011, 12, 69-74.

24. Instituto Nacional de Meteorologia do Brasil-INMET. Normais Climatológicas (1961/1990); INMET: Brasília, Brazil, 1992.

25. Zanin, D.S.; Fagherazzi, A.F.; Santos, A.M.; Martins, R.; Kretzschmar, A.A.; Rufato, L. Agronomic performance of cultivars and advanced selections of strawberry in the South Plateau of Santa Catarina State. Rev. Ceres 2019, 66, 159-167. [CrossRef]

26. Instituto Nacional de Metrologia Normalização e Qualidade Industrial-INMETRO. Informações Sobre Acreditação de Laboratórios; INMETRO: Rio de Janeiro, Brazil, 2005.

27. Devore, J.L. Probabilidade e Estatística Para Engenharia e Ciências; Cengage Learning Edições Ltda.: Sao Paulo, Brazil, 2010 ; p. 712.

28. R Core Team. R: A language and Environment for Statistical Computing; R Foundation for Statistical Computing: Vienna, Austria, 2013; Available online: http:/ / www.R-project.org/ (accessed on 2 September 2020).

29. Krause, R.V.; Mattoso, L.P.; Souza, E.R.; Vignolo, G.K.; Araújo, V.F.; Antunes, L.E.C. Influência da coroa de mudas de morangueiro das cultivares Aromas e Albion na precocidade da produção de frutas. In V Encontro de Iniciação Científica e Pós-Graduação da Embrapa Clima Temperado, Pelotas, Brasil; Embrapa Clima Temperado: Pelotas, Brazil, 2015.

30. Richter, A.F.; Ramos, R.F.; Rohrig, B.; Tonin, J.; Machado, J.T.M. Crescimento vegetativo de morangueiro através do uso de promotores de crescimento. Rev. Agric. Neotrop. 2019, 6, 76-81. [CrossRef]

31. Mochizuki, Y.; Ywasaki, Y.; Funayama, M.; Ninomyia, S.; Fuke, M.; New, Y.Y.; Yamada, M.; Ogiwara, I. Analysis of a high-yielding strawberry (Fragaria $\times$ ananassa Duch.) cultivar Benihoppe with focus on dry matter production and leaf photosynthetic rate. J. Jpn. Soc. Hortic. Sci. 2014, 82, 22-29. [CrossRef]

32. Cocco, C.; Gonçalves, M.A.; Picolotto, L.; Ferreira, L.V.; Antunes, L.E.C. Crescimento, desenvolvimento e produção de morangueiro a partir de mudas com diferentes volumes de torrão. Rev. Bras. Frutic. 2015, 37, 961-969. [CrossRef]

33. Hancock, J.F. Strawberries; CABI: Wallingford, UK, 1999; p. 237.

34. Gonçalves, M.A.; Picolotto, L.; Cocco, C.; Vignolo, G.K.; Antunes, L.E.C. Crescimento e desenvolvimento. In Morangueiro; Antunes, L.E.C., Reisser Júnior, C., Schwengber, J.E., Eds.; Embrapa: Brasília, Brazil, 2016; pp. 47-66.

35. Han, W.T.; Kim, Y.D.; Kang, S.G.; Moon, J.S.; Song, C.H.; Chang, J.I.; Park, Y.B. Studies on the establishment of hydroponics. 1. The effect of media on the quality and yield of strawberry in hydroponics. J. Agric. Sci. Hortic. 1993, 35, 401-409.

36. Hancock, J.F.; Sjulin, T.M.; Lobos, G.A. Strawberries. In Temperate Fruit Crop Breeding; Hancock, J.F., Ed.; Springer: Dordrecht, The Netherlands, 2008; pp. 393-437.

37. Carpenedo, S.; Antunes, L.E.C.; Treptow, R.O. Caracterização sensorial de morangos cultivados na região de Pelotas. Hortic. Bras. 2016, 34, 565-570. [CrossRef]

38. Matarazzo, P.H.M.; Siqueira, D.L.D.; Salomao, L.C.C.; Silva, D.F.P.D.; Cecon, P.R. Desenvolvimento dos frutos de lulo (Solanum quitoense Lam.) em Viçosa-MG. Rev. Bras. Frutic. 2013, 35, 131-142. [CrossRef]

39. Backes, D.B.; Cocco, C.; Schildt, G.W. Poda e renovação para o segundo ciclo produtivo e origem da muda de morangueiro. Rev. Eletr. Cient. Da Uergs 2020, 6, 110-119. [CrossRef]

40. Oliveira, A.C.B.; Bonow, S. Novos desafios para o melhoramento genético da cultura do morangueiro no Brasil. Inf. Agropecu. 2012, 33, 21-26.

41. Kovačević, D.B.; Putnik, P.; Dragović-Uzelac, V.; Vahčić, N.; Babojelić, M.S.; Levaj, B. Influences of organically and conventionally grown strawberry cultivars on anthocyanins content and color in purees and low-sugar jams. Food Chem. 2015, 181, 94-100. [CrossRef]

42. Cocco, C.; Magnani, S.; Maltoni, M.L.; Quacquarelli, I.; Cacchi, M.; Antunes, L.E.C.; D'Antuono, L.F.; Faedi, W.; Baruzzi, G. Effects of site and genotype on strawberry fruits quality traits and bioactive compounds. J. Berry Res. 2015, 5, 145-155. [CrossRef]

43. Aremu, C.O. Exploring statistical tools in measuring genetic diversity for crop improvement. In Genetic Diversity in Plants; Caliskan, M., Ed.; InTechOpen: Rijeka, Croatia, 2012; pp. 340-348.

44. Ematné, H.J.; Nunes, J.A.R.; Souza, J.C.; Muñoz, P.R. Genetic progress in popcorn recurrent selection by a multivariate mixedmodel approach. Ciênc. Agrotecnol. 2018, 42, 159-167.

45. Menzel, C.M.; Smith, L. Effect of Time of Planting and Plant Size on the Productivity of 'Festival' and 'Florida Fortuna' Strawberry Plants in a Subtropical Environment. HortTechnology 2012, 3, 330-337. [CrossRef] 